\section{Women Exhibitors at the First Australian International Exhibitions}

\section{Kirsten Orr}

University of Technology, Sydney ${ }^{1}$

In 1879 the British colony of New South Wales hosted the first international exhibition in the Southern Hemisphere. ${ }^{2}$ Never before had an international exhibition been held so far from the cultural and commercial centres of Europe. Exhibits and visitors from all the great nations of the world made the daunting sea journey to the remote and little-known colony that, less than forty years before, had been the destination mainly of convicts and their keepers. The Sydney International Exhibition was immediately followed by the Melbourne International Exhibition of 1880 in the neighbouring colony of Victoria, approximately six hundred miles to the south. The success of these exhibitions inspired the Melbourne Centennial International Exhibition, held in 1888 to celebrate one hundred years of white settlement in Australia. All 3 exhibitions were magnificent events to which almost everyone was welcome. ${ }^{3}$ These were events where visitors surveyed the greatest achievements of the age and participated enthusiastically in the festivities, the pomp and the ceremony.

This article examines new empirical data on the participation of colonial women as exhibitors at the Australian international exhibitions and the nature and extent of the items they exhibited. It compares the participation rate with data compiled by Paul Greenhalgh for the Paris Expositions Universelles (1855, 1867, 1878, 1889, 1900) and reveals that women in the Australian colonies participated as exhibitors at a significantly higher rate than their European and American sisters. Colonial women were living in settler societies, striving to maintain a spirit of Englishness and subscribing to the ideology of middle class gentility, with its principle of distinct gendered spheres of work, that was a common feature of the English-speaking middle classes throughout the British Empire. In this context, and supported by their previous experiences at intercolonial exhibitions, they were motivated to participate as exhibitors by a desire to take part in public life, to be recognised for their contributions to colonial progress and to promote women's work. The article garners specific examples of exhibited items from the exhibition catalogues to provide an insight into the nature and extent of women's contributions. Although the Australian international exhibitions primarily exposed colonial women to gendered views of productive work, they also provided independent and collective experiences that assisted women in the following decade to engage in social and political roles outside the home. There is an intriguing correspondence between the high participation rate of colonial women at the exhibitions and the fact that Australian women were among the first to achieve female suffrage.

\section{Background}

The Australian international exhibitions were modelled on their international counterparts and were housed in majestic, purpose-built exhibition halls reminiscent of the original Crystal Palace, built for the 1851 Great Exhibition in London. The Garden Palace in Sydney and the Royal Exhibition Building in Melbourne were uplifting spaces, surmounted by domes over the central points of their cruciform layouts and ornamented with statues and fountains. Exhibits were displayed in national courts ${ }^{4}$ that followed the established tradition of reflecting the world order and the power relations among the exhibiting countries, with the host nation taking pride of place. In the Garden Palace, the New South Wales exhibit was located under the dome flanked by Victoria and the other Australian colonies. In close relationship to New South Wales was Great Britain, diagonally opposite and occupying the largest area-an entire quadrant of the building. The longitudinal ceremonial axis divided the Old World from the New. America was located directly facing Great Britain as the equivalent power in the New World. There was a similar layout for the Melbourne International Exhibition the following year, although this time with Victoria at the centre. Exhibits were organized by a taxonomic classification system derived from the 1851 Great Exhibition.

To understand why colonial women participated as exhibitors at the Australian international exhibitions, it is necessary to consider aspects of the culture of colonial society in which they were living. The population considered itself "English," though now located on the other side of the world in a far-flung outpost of the British Empire, and maintained its Englishness by perpetuating cultural traditions and recreating "places of memory." 5 Even the growing number of Australian-born colonials who had never actually been to England developed imaginary constructs of what it was to be English. ${ }^{6}$ In hosting international exhibitions in Australia, the colonies looked to England for guidance and support. At the Australian exhibitions the arts and manufactures of the colonies were favourably compared to those of England and Great Britain, and provided "evidence of productive, creative British agency on the periphery. ${ }^{77}$ On a broader level than "Englishness," the population felt an ethnocentric superiority in belonging to the "white race." 8 They viewed the Australian Aborigines as innately different, as a race apart that was incapable of improvement or participation in civilized society. ${ }^{9}$ In fact, their Anglo-Saxon kinship and the very existence of Australia confirmed for many what Douglas Cole has described as: "the colonizing capacity and the indomitable energy of the race. The British had proven themselves to be the fittest race to occupy the world's vacant spaces; they were a people born to lead, to teach, and to better."10

By the time of the first Australian international exhibitions in 1879 and 1880, the colonies of New South Wales and Victoria were proud of the progress they had made. The frontier had been conquered, towns established, selfgovernment attained, and educational systems put in place. Melbourne was a booming metropolis and Sydney was experiencing steady growth. Progress underpinned the whole philosophy of colonial development and was informed by the theory of "course of empire" derived from the Scottish Enlightenment, which postulated that societies must pass through four consecutive stages-the hunting, the pastoral, the agricultural and the commercial-to reach the pinnacle of nationhood and empire. ${ }^{11}$ The progress made by the former penal colony of New South Wales and the frontier gold-rush settlement of Victoria was continually promoted at international
Journal of Colonialism and Colonial History Volume 12, Number 3, Winter 2011
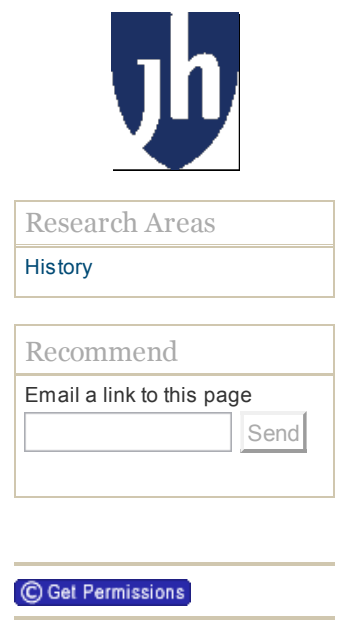

View Citation

Save Citation

\begin{tabular}{l} 
Frequently Downloaded \\
\hline Who Can Speak? Authority and \\
Authenticity in Olaudah \\
Equiano and Phillis Wheatley \\
Very Straight Sex: The \\
Development of Sexual Mores \\
in Jamaica \\
Bibliography of Books and \\
Articles Published in English \\
on Colonialism and \\
Imperialism in 2010
\end{tabular}

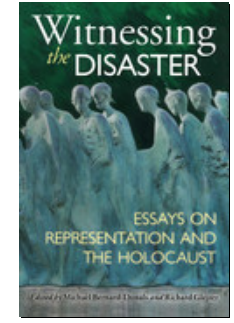

Witnessing the Disaster

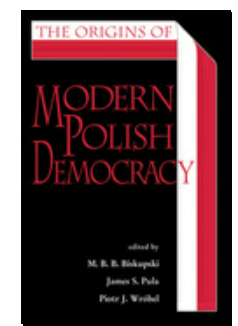

The Origins of Modern Polish Democracy 
exhibitions where ethnographic displays of indigenous peoples were surrounded by extensive collections of agricultural and mineral products, and surmounted with photographs of prominent public buildings and the rising cities of Sydney and Melbourne. ${ }^{12}$ Colonial pride culminated in a chorus of extravagant poetry and music at the Australian international exhibitions of 1879,1880 and 1888, and visions of colonial progress were extended to the higher destiny of nationhood.

Nineteenth century women throughout the English-speaking world were affected by new ideologies that accompanied the emergence of a large middle class. ${ }^{13}$ In Australia, this was delayed by the presence of a large, working class convict population and the middle class only began to grow with the arrival of free settlers from the 1850s onwards. Generally, the middle class distinguished itself from the working class by embracing the culture of gentility and appropriating behaviours and values associated with the aristocracy and, in the process, reformulated ideas about work and gendered roles. Whereas the aristocracy scorned paid labour, work was a necessity for the new middle class and, as Linda Young has argued, became "the source of respectable identity, the measure of the man" and an ennobling expression of duty that enabled the wife and children to live a life of leisure. ${ }^{14}$ An ideology of separate gendered spheres in which men worked in the public sphere and women were supported in the private sphere of the home was accompanied by a redefinition of working conditions that suited the needs of men but made it more difficult for women of all classes to undertake paid employment. ${ }^{15}$ This cultural shift was reflected in changes to the classification systems used in the nineteenth century censuses for New South Wales and Victoria. To a certain extent the Australian colonies followed the British occupational classifications, but the colonial statisticians Timothy A. Coghlan (New South Wales) and Henry H. Hayter (Victoria) gradually introduced systems in line with their own social philosophies in order to serve their colonies' interests. ${ }^{16}$ Because of the intense competition between the colonies for British investment, Desley Deacon argues, "each used the classification of women's work that projected the most flattering image." ${ }^{17}$ Australian-born Coghlan, influenced by the ideology of gentility, sought to portray a high standard of living among the middle classes—one where women were not required to work-and from 1871 he reduced the representation of women workers by not counting as productive workers any female relatives who were assisting in family enterprises. In contrast, Hayter, from a wellconnected British family, sought to portray a vital colony with a large and expanding workforce and to maximize the representation of women workers by automatically counting all the wives and daughters of farmers and the wives of small businessmen in their menfolk's occupational category. Although Hayter counted women in his statistics, he did not recognise them as possessing the attributes of the late nineteenth-century "New Woman," who had personal liberty, acted independently and challenged the limits set by a male-dominated society. The conflicting attitudes towards women's participation in productive work demonstrated by Coghlan and Hayter were evident at the international exhibitions in the nature of exhibits contributed by women and the extent to which they were integrated into the general (commercial) categories or confined to the ladies' courts. The vast comprehensiveness of the exhibitions welcomed all manner of exhibits, regardless of size, value, rarity, significance, usefulness or inventiveness. In this context gender-based tensions were revealed and challenged alongside other societal issues such as the competing ideologies of classicism and utilitarianism, the politics of empire and nation, and the value of the handcrafted versus the mass-produced.

Exhibition commissioners, drawn from the host nation's political, social and cultural elite, pushed their own agendas. The men appointed to organize the 1879 and 1880 exhibitions were charged with implementing statedirected objectives of raising their colonies' international profiles, stimulating trade, educating the population and promoting cultural advancement, but a detailed analysis of their individual backgrounds reveals a diverse range of personal motivations. ${ }^{18}$ In New South Wales, the commissioners shared a driving interest in the colony's moral improvement and cultural advancement, while in Victoria they were largely businessmen and manufacturers motivated by commercial interests and a concern for material progress. In both colonies, they subscribed to the established opinion that the home was an instrument for establishing civil and sexual order and for ensuring the moral calibre of society. ${ }^{19}$ By the 1870 s most Australians were no longer engaged in a pioneering role on the frontier but had become urban dwellers. ${ }^{20}$ Marriage rates for women were high and most women accepted the notion of separate spheres of work for men and women. By and large, women assumed domestic duties and became responsible for moral education in the home and their participation in social welfare activities was in roles largely determined for them by men. ${ }^{21}$

Motivations for Women to Exhibit

The Australian international exhibitions provided rare occasions for women to be recognized as independent participants in society at a time when they were otherwise absent from public life. They were yet to gain admission to university and the learned professions, they did not have the right to vote and even the wives of politicians were not invited to attend public banquets. ${ }^{22}$ However, in the exhibition arena, women from all walks of life were included as spectators, exhibitors, and consumers, comprising approximately fifty per cent of the audience. ${ }^{23}$

Many colonial women were already practiced at exhibiting in agricultural and intercolonial exhibitions held in the Australian colonies during the 1860 s and 1870s. This gave them the confidence to put themselves forward on the international stage. While the earlier agricultural and intercolonial exhibitions had been relatively small affairs, predominantly concerned with showcasing the products of the country's agricultural industry, there had been a handful of exhibition categories of specific interest to women. For instance, the 1870 Sydney Intercolonial Exhibition had twenty categories of which "Fine Arts," "Furniture and other objects for the use of dwellings," "Wine," "Dogs" and "Poultry" attracted female entries. ${ }^{24}$

The excitement generated by the extraordinary occasion of an international event in the Antipodes motivated colonial women to participate not only as spectators but also as exhibitors. No longer isolated from the rest of the world, they were now able to experience a grand exhibition at first hand, rather than reading about it in newspaper reports months later. This excitement was evident in the high general attendance rate. The executive commissioner for 1879 , Patrick Jennings, boasted that "the attendance is certainly unprecedented, and is by far the largest proportionately that has ever been recorded at any great International Exhibition held in any part of the world." 25 Similarly in Melbourne, attendance figures show that just about everyone attended the exhibitions. ${ }^{26}$ The only segment of the population unlikely to have attended in any sizeable number was the Australian Aboriginal community, which had effectively been excluded from mainstream society. ${ }^{27}$

Another motivation for women to exhibit was pride in the social and material progress of their colonies. The exhibitions were celebrations of colonial achievement and inspired their support. Women may have also have been caught up in the competitive rivalry between the colonies to attract international investment, labour and trade, 
therefore exhibiting in support of their particular colony. Women were also motivated as exhibitors by their desire to contribute items of interest to other women and to demonstrate that they were not idle in the home. Whether in frontier settlements or in the growing towns and cities, women's experiences were intimately interwoven with the family and their identities were defined by family life in which they constituted the essential moral and spiritual core. Participating as exhibitors in Australian international exhibitions gave them an opportunity not only to demonstrate their skills as homemakers but to prove that they possessed the same civilising qualities and middle class standards as British family women that were essential for promoting colonial progress and prosperity. ${ }^{28}$

The opportunity to promote female commercial interests must also have been at play. Martha Sear observes that the international exhibitions were conceptualised as non-commercial displays that transcended the "debasing forces of the marketplace." 29 In contrast, the Exhibition of Women's Industries and Centenary Fair, organized by a committee of women in Sydney in 1888, the same year as the Melbourne Centennial Exhibition, was structured as a bazaar at which women could exhibit and sell their work directly from the floor. ${ }^{30}$ The success of the Exhibition of Women's Industries and Centenary Fair suggests that the high ideals of the international exhibitions did not fully meet women's needs and that they wanted to actively enter the marketplace and be recognized as productive workers.

The nature and artistry of the products that women chose to exhibit displayed a female interest in the uniqueness of the Australian continent that they wished to bring to the attention of the world. The international exhibitions traditionally provided opportunities to display objects representing national character: Belgium was renowned for its pianofortes; Italy for its sculpture and mosaics; and so on. In this setting, comparisons between nations and what Jennings called the "distinctive peculiarities" of their products were constantly made. ${ }^{31}$ In strong contrast to the pillars of gold, bales of wool and other items that were largely derived from the work of men, women showed items inspired by native flora and fauna and useful items suited to the Australian home that were distinctly different from their English and European counterparts and which suggested a movement away from representations of Englishness as a prescriptive ideology.

Statistical Analysis of Australian Colonial Women's Participation as Exhibitors

Compared to other international exhibitions before and after, colonial women participated as exhibitors in the Australian international exhibitions at a much higher rate than their European and American sisters. Greenhalgh's analysis of women exhibiting at the first five Paris Expositions Universelles (1855, 1867, 1878, 1889, 1900) demonstrates the considerable variance in the percentage of women exhibitors from various nations in Europe and America. This article undertakes a similar analysis of the first Australian international exhibitions held in Sydney (1879) and Melbourne (1880), and the Melbourne Centennial International Exhibition (1888). However, it differs from Greenhalgh's approach by focussing on the contribution rates of women from the different Australian colonies, rather than from different nations. The analysis is provided in a series of 5 tables, as follows:

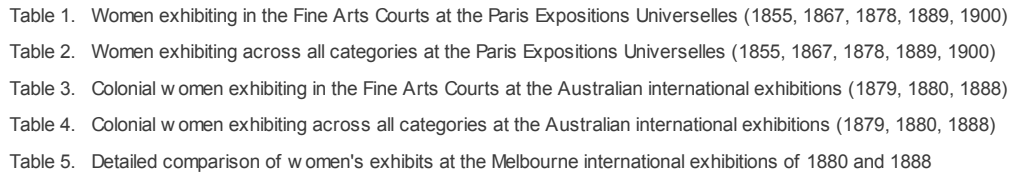

Table 1

Greenhalgh analyses the contributions of women to the Fine Arts Courts in Paris because these were the most prestigious exhibition displays. ${ }^{32}$ Table 1 presents his calculations of the percentage of women artists amongst the eleven most prominent nations at the Paris Expositions Universelles: in 1878, the year before the Sydney International Exhibition, only 3.3 per cent of the artists were women. Over the period from 1855 to 1900 there was no clear linear progression in percentages that might suggest increasing gender equality in the fine arts.

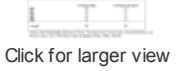

Table 1.

Percentage of women artists amongst the eleven most prominent nations exhibiting in the Fine Arts courts at Paris Expositions Universelles $(1855,1867,1878,1889,1900)$

Table 2

The national contingents of participating nations varied considerably in size. For instance at the Paris Expositions Universelles, France, as the host nation, naturally had the largest contingent, while its competitor Britain had a larger contingent than the other foreign nations. Table 2 shows the proportion of women exhibiting across all categories as a percentage of their national contingent.

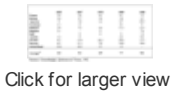

\section{Table 2.}

Percentage of women exhibitors amongst the eleven most prominent nations across all categories at Paris Expositions Universelles (1855, $1867,1878,1889,1900)$

In 1878, the year before the Sydney International Exhibition, the percentage of women exhibitors was 4.5 per cent for France, 3.8 per cent for Britain and 1.2 per cent for America. ${ }^{35}$ Greenhalgh finds that although there was an unwillingness on the part of organizers to give women much room in the general categories, numbers of women did succeed in having their work seen. Moreover, there was considerable variance between nations, particularly in art. Although France and Britain had the greatest numbers of participating women artists, Sweden had the highest number of female exhibitors as a proportion of the national contingent, and by 1900 American women were taking big strides and represented twenty per cent of the country's total. ${ }^{36}$

Table 3 
My analysis of the Australian statistics, presented in Table 3, reveals that the Paris participation rates of female art exhibitors were eclipsed by those of Sydney and Melbourne: the percentage of Australian colonial women artists exhibiting was 18.6 per cent in 1879 and 18 per cent in 1880 , rising to 23.5 per cent in 1888 .

\section{Table 3.}

Percentage of colonial women artists exhibiting in the Fine Arts courts

at Australian International Exhibitions (1879, 1880, 1888)

Click for larger view

A closer look at Table 3 reveals a great disparity in the number of women exhibiting from different colonies. One factor affecting this disparity is the proximity of the various colonial populations to the exhibition cities. For example, it is not surprising that the largest contingent for the 1879 exhibition held in Sydney, the capital of New South Wales, came from that colony. The colony of South Australia had a strong female showing for the exhibitions in 1880 and 1888 in Melbourne with which it had close shipping ties, but a much smaller showing for the 1879 exhibition in Sydney which was further away.

The different characters of the colonies must have been another factor that affected the rate of female participation as exhibitors. One has to ask why, when Melbourne and Sydney were in close communication with one another, the contingent of women drawn from the Colony of Victoria for the 1879 exhibition was small and why relatively few Victorian women exhibited at the 1880 and 1888 exhibitions held in their own capital city of Melbourne. Melbourne was what journalist and author Richard Twopeny described as the wealthy "metropolis of the Southern Hemisphere," 37 a city of impressive classical-style buildings and wide boulevards that were likened to those of Paris. It is possible that Victorians had greater exposure to the fine arts and possessed a higher level of artistic discrimination, which inhibited the participation of their amateur and unrecognized women artists as exhibitors. In contrast, Sydney-lacking the cultural institutions of Melbourne, and having what one former Sydney resident described in 1887 as "the stamp of inferiority to Melbourne in everything: streets, people, buildings, etc." ${ }^{38}$ _attracted larger numbers of female exhibitors. There had been considerable discussion in New South Wales about the educative value of the exhibition and women were motivated to support its potential for social and cultural advancement.

South Australia was different again from either Victoria or New South Wales in that Adelaide had originated as a carefully planned town of free settlers. The high numbers of women exhibiting from this colony were possibly supporting their colony's need to attract investment and suitable immigrants. Tasmanian women were particularly enthusiastic exhibitors, which might seem surprising given the colony's more recent penal history and island location on the periphery of continental Australia. But as indicated in the contemporary writings of Louisa Meredith, women's work held significant social, cultural and economic value for a frontier society. Her narratives recount her efforts to recreate the pastoral bliss of English country life in Tasmania's relatively cold and damp climate, as well as her experiences as a "homemaker" establishing a comfortable home, keeping up middle class standards of gentility and supporting her husband's work. ${ }^{39}$

Competing exhibition events in neighbouring colonies almost certainly had an impact on exhibition rates. For example, relatively few New South Wales women sent items to the Melbourne exhibition of 1880 and this may have been due to its close proximity to the exhibition of 1879 in Sydney, which had closed only 5 months earlier. The number of women from New South Wales sending items to the exhibition in 1888 was even lower. ${ }^{40}$ This might be explained by the Exhibition of Women's Industries and Centenary Fair, which was held separately in Sydney during the same period as a major part of the New South Wales centennial celebrations. ${ }^{41}$

Table 4

Table 4 shows the percentage of women exhibitors excluding fine arts exhibits, followed by the percentage of women exhibitors across all categories of exhibits. My figures show that the percentage of colonial women exhibitors across all categories was 13.8 per cent in 1879, 12.2 per cent in 1880 and 11.3 per cent in 1888-the participation rate in 1879 being almost 3 times the average participation of women from the eleven most prominent nations at the Paris Exposition Universelle in 1878.

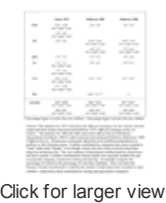

Table 4.

Percentage of colonial women exhibiting across all categories at

Australian International Exhibitions (1879, 1880, 1888)

There is very little difference between the percentage figures that exclude fine arts exhibits (marked with *) and the percentage figures that include them (marked with ${ }^{\wedge}$ ), which indicates how little work by colonial women was exhibited in the prestigious fine arts courts. There is a large difference, however, between the figures that include work exhibited in the Ladies' Court and the figures that exclude work exhibited there. Items contributed to the exhibitions were classified and displayed in a series of general classes that ranged from the artistic, such as "Oil Paintings" and "Sculpture and Die Sinking," to the technical such as "Mining and Metallurgy." Only twenty per cent of the work exhibited by New South Wales women in 1879 was integrated into these general exhibition classes. It was a similar story at the Melbourne exhibitions where only twenty-two per cent of the work exhibited by Victorian women in 1880 and thirty-seven per cent in 1888 was integrated into the general exhibition classes. The anomaly is Tasmania, whose women exhibited two-thirds of their items in the general exhibition classes in 1879. The figures reveal the significance of the ladies' courts, which accommodated the majority of items exhibited by colonial women. While these courts made women's work visible, their lack of integration with the general exhibition classes perpetuated the notion that women's work was not economically significant. ${ }^{43}$ In fact, The Sydney Morning Herald praised the Ladies' Court for encouraging the "intellectual and refined employment" of colonial women in artistic pursuits during their leisure hours." 44 Moreover, some work on display was of very poor quality and it was noted that it was a great pity "some standard of merit" had not been required before works were 

accepted for display." 45

Table 5

Table 5 shows the general exhibition classes to which women contributed exhibits in 1880 and 1888 . The description and numbering of classes at the 2 Melbourne exhibitions were virtually identical, making direct comparison between them possible. The Sydney International Exhibition has not been included in this table because it adopted an altogether different system of classification, making the data difficult to compare.

The figures are listed by colony: starting with New South Wales and followed by Victoria, Queensland, South Australia, Tasmania and Western Australia. The first figure shows the number of women, the second the total number of exhibitors in that class. A dash indicates that no women were represented by a particular colony in that class. For example, in 1880 in Class 1-"Oil Paintings"—4 of the 20 exhibitors from New South Wales were women, 9 of the 48 exhibitors from Victoria were women, there were no female exhibitors from Queensland, 4 of the 12 exhibitors from South Australia were women, 2 of the 11 exhibitors from Tasmania were women, and there were no exhibitors from Western Australia.

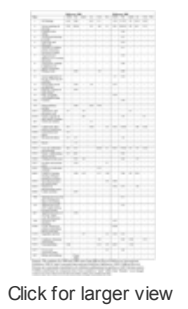

Table 5.

Contributions of colonial women to general classes of exhibits at the

Melbourne International Exhibitions in 1880 and 1888

The figures show that female contributions to the general exhibition classes were confined to relatively few categories, the most popular being those associated with arts and crafts. Class 2-"Various paintings and Drawings"-attracted the most female participation, with Victorian women contributing forty-four per cent of the exhibits at both Melbourne exhibitions, and a strong representation of South Australian and Tasmanian women. Women also contributed to Class 1-"Oil Paintings"—comprising roughly twenty per cent of the exhibitors. The notable exception was the Victorian female participation in this class in 1888 where the lower rate might be explained by the emergence of recognized groups of professional artists in that colony, such as the Heidelberg School. The classes for "Lace, Net, Embroidery and Trimmings" and for "Leatherwork, Fancy Articles and Basketwork" were also popular with female exhibitors. In other classes, such as "Furniture" or "Medicine, Hygiene and Public Relief," there were isolated exhibits contributed by women that tended to be closely related to their traditional domestic interests. Women did not exhibit hardware, ironmongery or metallic products but showed fancy furniture; exotic and utilitarian items from animal skins, fur and feathers; chemical and pharmaceutical products, condiments and fermented drinks.

The Ladies' Courts

From the first Great Exhibition of 1851, when the Duchess of Sutherland formed a ladies' committee of wealthy London women, including the wives of several organizers, "to consider the best means of forwarding the objects of the Exhibition," women played occasional and minor roles in the preparations for international exhibitions ${ }^{46}$ But they were not officially appointed as commissioners and their contributions were marginalized and largely hidden from view in ladies' organising committees and juries that frequently went unlisted in the Official Records. While the Philadelphia Centennial Exhibition of 1876 broke new ground with the official appointment of a women's centennial executive to direct the impressive Woman's Building, ${ }^{47}$ the involvement of women in an organizational capacity for the Sydney International Exhibition of 1879 appears to have been virtually non-existent. John Alger, one of the New South Wales commissioners who had recently returned from Philadelphia, supervised arrangements for the Ladies' Court. Léon Moonen from Paris, assisted by Moritz Bahse from Germany, chaired the jury-making, one suspects, all the important decisions on awards. ${ }^{48}$ At the ensuing international exhibitions in Melbourne, arrangements for the ladies' courts and judging were placed in female hands, but exactly whose hands is unknown. ${ }^{49}$

Most women's exhibits were to be found in the ladies' courts, as shown in Table 4. In 1879 women sent a total of three hundred exhibits, of which 179 (60 per cent) were displayed in the Ladies' Court situated under the Eastern Tower of the Garden Palace, the rest being in the general exhibition classes. Similarly, in 1880, 372 exhibits were contributed by women, of which 241 (65 per cent) were in the Ladies' Court. By 1888 the Ladies' Court had become a substantial suite of 12 rooms, open to the Victorian Court on one side for its whole length, containing 230 (64 per cent) of the total 361 exhibits contributed by women. ${ }^{50}$

Women's Work

Much of the women's work displayed at the Australian international exhibitions was notable for the way in which it demonstrated what Kate Darian Smith has described as the "adaptive artistic capacity of British women from the outposts of Empire." 51 In the fine arts, European styles were applied to Australian subject matter. In the applied arts, British decorative and utilitarian wares were emulated with the Australian twist of using materials available in the colonies. British styles and conventions were imported, but adapted to new materials and circumstances.

The artist Marian Ellis Rowan combined an awareness of European developments in painting, the genre of botanical flower painting and the preferred feminine medium of watercolour, to achieve international acclaim as a painter of Australian wildflowers. She won 10 gold, 15 silver and 4 bronze medals at international exhibitions of art and industry during her career. She was the only Australian artist to win a gold medal at the Melbourne Centennial International Exhibition and her success aroused the envy of Melbourne's male professional artists, who disparaged her work. The criticism was probably not provoked by her progressive style, but possibly, as Kerry Heckenberg contends, by her "challenge to the traditional boundaries of gender and genre." 52 By the late 1880 s the Melbourne art world had become strongly politicized and distinctions were being made between high art, decorative art and botanical art. Rowan's work did not sit comfortably in any genre, being too decorative for high art and lacking the finer details and accuracy required for botanical art. As a botanically aware artist in search of the picturesque, she collaborated with the government botanist of Victoria, Ferdinand Mueller, made expeditions to the remote tropics of Queensland and travelled the world searching for subject matter. ${ }^{53}$ The Official Record reported that in 1880 the most "prominent feature of attraction" on entering the Victorian Gallery was Mrs. Rowan's four- 
leaved screen featuring "beautiful arrangements of the native flowers of Victoria, New Zealand and New South Wales, executed in watercolours upon black, pale yellow, pale blue, and crimson satin." 54

Rowan's paintings were neither quite European nor quite Australian and, as such, exemplified the way in which colonial society could be both British and Australian at the same time. Since the Great Exhibition of 1851, Australian exhibits had always included silverware such as trophies and jewellery featuring Australian motifs of Aborigines, kangaroos and the Southern Cross (a distinctive constellation found in the southern region of the night sky, comprising four bright stars in the formation of a Latin cross). Notes on the Sydney International Exhibition of 1879 explained that while "this may seem to European eyes a strange style of art, yet it is undoubtedly in excellent taste for colonial artists to imitate the natural forms peculiar to this new continent." ${ }^{55}$ Australian colonial society was attempting to define its identity: recognising its British heritage yet beginning to acknowledge the differences existing between Australian-born colonials and their British forebears. These differences arose from the geographic environment and the informal lifestyle it dictated, the tyranny of distance and the dominance of a large working class population. ${ }^{56}$ Australian women produced decorative objects that combined Australian imagery with native products. For example, Miss Waterhouse decorated an English-style table top with a pattern of ferns that the jury found to be "very pretty... the fern design coming out very clearly. The whole exhibit is carefully finished, attractive and original;" 57 while Miss Hely and Miss Hooper displayed cone frames and painted Huon pine tabletops. ${ }^{58}$ Such exhibits demonstrated a connection to the land and the female shaping of an emerging Australian identity.

These white colonial women accepted without question their right to establish homes on "erstwhile Aboriginal lands" and their right to transform aspects of their new country to arrive at versions of the old. ${ }^{59}$ The original Aboriginal owners had been driven off the traditional lands belonging to their language groups and were excluded from the new civilization being imposed by colonial society. The exhibitions legitimated this process by displaying the work of Australian Aboriginal men and women as anthropological curiosities. Aboriginal women's work was exhibited not by the women themselves, but by public and private collectors in ethnological displays that featured photographs, artwork, woven baskets and cooking utensils as the artefacts of a primitive race. ${ }^{60}$

In the judging of the applied arts in the Ladies Court in 1879, Moonen and his jury favoured articles that demonstrated "perfection in graceful conception and artistic taste" and were useful for decorating the domestic interior or enhancing ladies' attire. ${ }^{61}$ Along these lines, Miss Elizabeth Billinghurst exhibited "a shade of emu eggs, mounted with silver, carved and painted with a likeness of Mr. Buckley, ${ }^{62}$ who was seventeen years with the Blacks;" Miss Fuller sent "needlework for drawing room furniture, consisting of mantelpiece hanging, tablecloth, chair hand-screen and anti-macassar;" and Mrs. Murray showed "knitted mittens in imitation of lace."63 In 1880 and 1888, emphasis was again on arts and crafts and the items on show were pretty, decorative and domestic and shared a predominantly floral theme. There was a proliferation of painted flowers and floral wreaths on all manner of domestic furnishings, and an abundance of glass cases and shades filled with every variety of wax and paper flower and fruit. Useful feminine crafts such as lace, needlework, patchwork quilts, and tatting were plentiful. Women's efforts as collectors were well represented with bouquets of fish scales and cuttlefish, feathers of native birds "tastefully designed" in garlands of flowers, albums of leaves and ferns, seaweed "arranged in every variety of form," and decorated emu eggs. Fancy leatherwork and cone-work were popular, providing elaborate ornamentation for sitting room furniture and mirror frames. ${ }^{64}$

There is little contemporary comment by women or men to indicate what people thought about the women's work displayed at the international exhibitions. The Australian publishing industry was in its infancy in the 1880s and, although flourishing, there were no lasting women's magazines until the Dawn - A Journal for Australian Women (1888-1905). Women read magazines imported from Britain that fed nostalgia for their English "home." The popular Sydney journal of the 1880 s was the Bulletin in which masculinist attitudes reflected the predominantly patriarchal mood of colonial Australia. From the 1870 s female journalists worked on women's pages in various mainstream newspapers offering social gossip, cookery and fashion advice and reinforcing the idea that a woman's place was in the home. Such pages shared similarities with the ladies' courts at the exhibitions, being exclusively for women and lacking integration with the other pages of the newspaper. Female journalists working on the women's pages could not be promoted to other positions on the newspaper staff. There were a few female social reformers writing under pseudonyms, such as Catherine Helen Spence in South Australia, but on the whole any attempt to educate Australian women in the social or political issues of the day was strenuously avoided. ${ }^{65}$

One of the few female perspectives on women's work at the exhibitions can be found in the fictional accounts of Ada Cambridge. She came from a comparatively well-to-do background and had left England for Melbourne in 1870 as a young woman married to a clergyman. Her novels, The Three Miss Kings (serialized in 1883) and A Woman's Friendship (serialized in 1889-90), featured the 1880 Melbourne International Exhibition and the 1888 Melbourne Centennial Exhibition respectively. Her heroines found the exhibition setting an ideal venue for meeting with their female and male friends and they revelled in the unaccustomed liberties and newfound sense of independence afforded by the exhibitions. The 1888 Ladies' Court appalled them:

Patty repaired to a given rendezvous in the Ladies' Court, and there found her bosom friend in a state of shuddering indignation at the horrors exposed around her. "Oh, Patty," she cried—-they w ere her first w ords of greeting —"look, look at these things! lsn't it aw ful?" She pointed to the bead w ork and the crochet w ork and the wax flow er w ork and the Berlin w ool and crew el w ork as at so many gory corpses. "Did you think such monstrosities had survived to these days? Oh, to think there are women, and so many of them, capable of such deeds-still!" Her voice was a wail of anguish. "Come aw ay, darling —let us go upstairs and try to forget it." They w ent to the German picture gallery, and that consoled her. ${ }^{66}$

The picture galleries and concert hall became the special domains of Cambridge's heroines, who spent every available moment there. The great masterpieces from Europe provided the backdrop to their earnest discussions about women's issues of the day, such as the franchise, dress, diet, marriage and divorce. Cambridge's novels set up parallels between the characteristics of the objects in the exhibitions and the personal qualities and values of her female and male characters. ${ }^{67}$ It is significant that these women preferred the German picture galleries. Through their appreciation of high culture they showed themselves to possess refined tastes. In contrast, the items on display in the Ladies' Court were considered to be in poor taste, being either utilitarian or over-decorated and frivolous. It was generally recognized at the time that the material conditions of gentility dictated one's choice of goods: the fundamental values of genteel taste were restraint, appropriateness for purpose, high quality and avoidance of ostentation and conspicuous consumption. ${ }^{68}$ 
The exhibits contributed by women to the general exhibition classes showed them to be rational, hard working and enterprising. Who could be more rational than Mrs. E.M. Perryman, the inventor of a marine clock and striking ships bells, designed to keep time in heavy seas; ${ }^{69}$ or more hard-working than Mrs. C.C. Armstrong who received a First Order of Merit for her collection of 150 dried specimens of ferns in presentation form; ${ }^{70}$ or more enterprising than the Misses Armfield who received a commendation "for novelty and usefulness" for their Opossum fur socks? ${ }^{71}$

Clearly women were contributing to the development of the Australian colonies by engaging in agriculture, science, and manufacturing. This was demonstrated at the exhibitions by numerous exhibits such as Mrs. Blayden Neill's raw and manufactured silk, which received a First Degree of Merit and a citation from the jury, that "from the fact of the exhibitor having 50 acres under mulberry cultivation, her success is a matter of public importance."72 Amateur scientific collector, Mrs. J.A. Bailey from Victoria received a First Order of Merit for her collection of shells and fossils in $1888 .{ }^{73}$ Items of interest to manufacturers were Victorian Mrs. Nellie Sexton's window sashes and roller blinds which won a Third Order of Merit in $1880 .^{74}$

Some of the women complemented the work of their husbands, and their exhibits showed that they were actively involved in their husbands' enterprises. In census data collected by Coghlan in New South Wales, these women were probably classified as being dependents, not productive workers, and their work may not have been recognized in the public sphere. In 1888, Mrs. Onslow, wife of the wealthy New South Wales pastoralist, exhibited twelve fleeces_including wool, merino, ewes and greasy ${ }^{75}$ _and a collection of farm and garden seeds, while Mrs Penfold, wife of the New South Wales vigneron (still well known today), exhibited wines in 1879. More significantly, Mrs. Elizabeth Coxen, who had collaborated for many years with her husband Charles (the first Vice President of the Queensland Philosophical Society and founder of the Queensland Museum), continued the work after his death. She won awards for her collections of stuffed birds, coral and shells, became recognized in her own right as an important pioneer naturalist, and was the first woman to be employed by the Queensland Museum. ${ }^{76}$

Other women who were actively involved in various professions and thus contributing to the progress of the Australian colonies submitted exhibits related to their work. Miss F.C. Niven was one of eight Victorian architects commended for their architectural drawings that "spoke well of the profession in Victoria." 77 In 1888 Miss Emily Axford showed a specimen of Pitman's shorthand, while Miss Margaret Cross exhibited a specimen book of commercial typography.

Long-Term Significance of Female Participation

Virginia Grant Darney has assessed the changing nature of women's exhibits at the American international exhibitions of 1876, 1893, 1895 and 1904 to argue that the Philadelphia Centennial Exhibition established a pattern for future fairs. It "fostered the beginnings of women's organizations and encouraged the weaving of a woman's network to connect women interested in social and educational reform. This network, which eventually included a wide spectrum of political positions, first reflected and then fostered female solidarity."78

Whereas the 1876 Philadelphia Centennial Exhibition celebrated one hundred years of American nationhood, the Australian international exhibitions of 1879, 1880 and 1888 were held before the federation of the Australian colonies but coincided with greater educational opportunities for women. Women were admitted to the Universities of Sydney, Melbourne and Adelaide from 1881, earlier than in most other countries, and this early access produced a trickle of female graduates who moved into teaching and the professions. Working class women, meanwhile, took up employment in factories, shops and service industries in unprecedented numbers. ${ }^{79} \mathrm{~A}$ change was taking place in colonial society as women increased their participation in the public sphere of paid work. This was accompanied by the involvement of women in professional and auxiliary bodies lobbying for better work conditions, and in philanthropic, charitable and literary societies concerned with social and political issues, such as female suffrage. For example, in Sydney the Woman's Christian Temperance Union (WCTU) was established in 1885 and the Womanhood Suffrage League in 1891. In Melbourne the WCTU was established in 1887, the Woman's Suffrage League in 1894 and the first union of women workers, the Tailoresses Union, in 1882. These groups encouraged the development of common interests beyond domestic matters and informed opinion on social and political issues. Many of them joined forces around 1895 to form national councils of women around Australia. ${ }^{80}$ The exhibitions, boosted by later colonial exhibitions of women's work such as Sydney's Exhibition of Women's Industries and Centenary Fair (1888) and Woman's Work Exhibition, held at the Sydney Town Hall (1892), provided a platform for women to develop confidence, build networks and gain exposure as leaders in public life.

A number of women drew upon their exhibition experiences to engage with the public sphere in a variety of social and political roles. Frances Lewy who had exhibited watercolour paintings in 1879 and $1880^{81}$ later became honorary secretary of the Women's Society for Prevention of Cruelty to Animals. ${ }^{82}$ Lady Mary Windeyer who was president of the New South Wales Woman's Work Committee for the World's Columbian Exhibition of 1893 became president of the Womanhood Suffrage League of New South Wales. Her daughter, Margaret Windeyer, the only foreign woman appointed to the Congress of Women held in conjunction with the Columbian Exhibition, became the honourable secretary of the League. A number of the wives who would have stood behind their men in the organization of the Australian international exhibitions went on to play independent roles in the federation movement. Eliza (Lizzie) Ashton, wife of artist and National Art Gallery Trustee Julian Ashton, became a founding member of the New South Wales National Council of Women (1896); Jean Barton, wife of Australia's first prime minister Edmund Barton, became a founding member of the Women's Federal League (1898); and Juliette Henry, wife of the prominent French immigrant artist Lucien Henry, was well known for her keen interest in politics and the welfare of her adoptive country. In this environment of intensifying female involvement in the public sphere, Louisa Lawson established the first long-lived publication for women, the Dawn, and as editor asserted the dignity of women and attacked misogyny and the stereotyping of women. On one occasion she offered a rare vote of sympathy for the plight of Australian Aboriginal women, urging white women to be charitable towards them. ${ }^{83}$

There is an intriguing correspondence between the high participation rate of women at the Australian international exhibitions and the fact that the Australian colonies were among the first to achieve female suffrage. Patricia Grimshaw says that:

The male legislatures which extended w omen the suffrage betw een the years 1890 and 1902 w ere... four states of the American West (Wyoming, Utah, Colorado and Idaho); the British colonies of South Australia and Western Australia, follow ed by the Commonw ealth of Australia and the state of New South Wales; and... New Zealand. These were all 
small societies, marginal geographically to the political main-springs of the women's movement. ${ }^{84}$

In all of the above cases white settlers had displaced indigenous peoples, and men predominated and had the right to vote. "Liberalism was a strong force and there was pressure for greater state intervention [and reform] in social issues," such as temperance, argues Grimshaw. ${ }^{85}$ Temperance was promulgated through the WCTU, an organization which had been founded in Illinois in 1873 and soon spread to New Zealand and Australia. While the purpose of the WCTU was to combat the influence of alcohol on families and society, it grew to encompass a wide range of social reform issues. In Australia, the WCTU was the first of 3 main groups (the others being the Women's Suffrage League and the Working Women's Trade Union) to campaign for women's suffrage.

It could be that, just as the Australian colonies were early to achieve women's suffrage on the back of mora issues such as temperance, these same conditions influenced the readiness of women to participate in the Australian international exhibitions. The belief that moral values were nurtured in the home inspired women to display domestic items to improve home comfort and provide an attractive environment for family life. Many dismissed the craftwork in the ladies' courts as inferior to the fine arts and manufactured goods featured in the other courts. However, this work was important because it promoted the value of the home as a civilising force ${ }^{86}$ in the Australian colonies, and demonstrated the desire of women to contribute to the advancement of their colonies at a time when they were excluded from public life. Participation in the exhibitions made it possible for women to begin to "articulate the cultural implications" of a paradox which saw them as the guardians of social values but without any voice in the formation of the laws that ruled them. ${ }^{87}$ They had an opportunity to speak publicly of their role as homemakers and to project a dichotomous image of women engaged in the public sphere through work produced in the private sphere. The achievement of female suffrage also depended upon women becoming active in the public sphere and working collectively on matters of social and political interest. The exhibitions provided an early venue for women to act not just as individuals but collectively, and those women who exhibited and became active in the exhibition movement gained valuable experience in contributing to a collective enterprise.

\section{Conclusion}

Nineteenth century exhibitions gave colonial women opportunities to participate in society at a time when they were largely excluded from public life. At the Australian international exhibitions of 1879, 1880 and 1888, colonial women were enthusiastic exhibitors-their participation rate in 1879 being almost 3 times greater than their European and American sisters at the earlier Paris Exposition Universelle. This article has explored possible explanations for the unprecedented rate of female participation in the context of the characteristics of colonial society; the nature and novelty of the Australian exhibitions; and women's prior experiences at intercolonial exhibitions.

The exhibitions established a public sphere of influence that gave women an opportunity to demonstrate their accomplishments and to recognize their personal value as individuals in a male-dominated society. The display of women's work at the exhibitions made them visible as productive workers at a time when they were officially classified as unproductive dependents. Contributions included handcrafted domestic items, works of fine art, scientific collections and manufactured products and demonstrated women's creativity and adaptability in the fashioning of goods for comfort, refinement and colonial progress. They were noticed as active agents in the shaping of colonial culture and identity.

In the 1880 s colonial women began to take a leading role in society and public discourse by forming and managing societies in pursuit of social reform. From this emerged what could be regarded in the Australian context as an early appearance of the "New Woman," acting independently and beyond the confines of gender. Women who had previously accepted a life confined to the private sphere had the opportunity to test themselves in the commercial and political environment of the exhibitions and in doing so gained knowledge, networks and experience that enabled them to extend their activities into public life.

Notes

\footnotetext{
1. For correspondence: kirsten.orr@uts.edu.au.
}

2. An earlier exhibition staged in 1865 in Dunedin, New Zealand, w as conceived as an "Industrial Exhibition" and although it was intended to be much more comprehensive than the "merely local" exhibitions, it was "very restricted and humble when contrasted $w$ ith those of the Great International Exhibitions." New Zealand Exhibition, 1865: Reports and awards of the jurors and appendix (Dunedin: Mills, Dick and Co, 1866), v. It included exhibits from Britain and the colonies but did not receive patronage from the governments of Europe or America. Official Catalogue of the New Zealand Industrial Exhibition, 1865 (Dunedin, 1865).

3. Not everyone was welcome. Exclusion on the basis of race, class and gender took various forms-access to the exhibitions $w$ as sometimes restricted; and the exhibits, classification system and presentation of aw ards misrepresented some groups, failed to acknow ledge others and created distorted images of "civilization" and "savagery."

4. The national courts were areas of floor space of various sizes that were set aside for each country, clearly demarcated by bunting and national symbols. They were divided into smaller chambers as required.

5. lan Baucom, Out of Place: Englishness, empire and the locations of identity (Princeton: Princeton University Press, 1999), 10. 6. Andrew Hassam, Through Australian Eyes: Colonial perceptions of Imperial Britain (Carlton South: Melbourne University Press, 2000), 27.

7. Linda Young, "'How like England we can be': The Australian International Exhibitions in the nineteenth century," in Seize the Day: Exhibitions, Australia and the world, ed. Kate Darian-Smith et al. (Clayton: Monash University ePress, 2008), 12.2.

8. Douglas Cole, "'The Crimson Thread of Kinship:' Ethnic ideas in Australia, 1870-1914," Historical Studies 14: 56 (1971): 512

9. Robert Dixon, The Course of Empire: Neo-classical culture in New South Wales 1788-1860 (Melbourne: Oxford University Press, 1986), 1-5; Luke Trainor, British Imperialism and Australian Nationalism: Manipulation, conflict and compromise in the late nineteenth century (Cambridge: Cambridge University Press, 1994), 168.

10. Cole, "'The Crimson Thread of Kinship,"' 514.

11. Dixon, The Course of Empire, 1-5.

12. Kirsten Orr, "A Force for Federation: International exhibitions and the formation of Australian ethos (1851-1901)" (PhD diss., University of New South Wales, 2006), 229-231.

13. Linda Young defines the emergence of the middle class as having occurred in the long period stretching from the 1780 s to 1914 during which a genteel culture was flow ering in the British Empire and America. Linda Young, Middle-Class Culture in the Nineteenth Century: America, Australia and Britain, (Basingstoke: Palgrave, 2003), 5.

14. Ibid., 72

15. Patricia Grimshaw, "'Man's Ow n Country:' Women in colonial Australian history," in Australian Women: New Feminist Perspectives, eds. Ailsa Burns and Norma Grieve (Oxford: Oxford University Press, 1986), 198-201. 
16. Timothy Augustine Coghlan was the New South Wales Government Statistician from 1886-1905. Henry Haylen Hayter was the Assistant Registrar-General of Victoria and first government statistician from 1859-1895.

17. Desley Deacon, "Political Arithmetic: The nineteenth-century Australian Census and the construction of the dependent woman," Journal of Women in Culture and Society 11:1 (1985): 38.

18. Orr, "A Force for Federation," 81-134.

19. Kirsten Orr, "Colonial Ambition and City Development: The influence of commissioners for the 1879 International Exhibition on Sydney's architectural identity," in History in Practice: 25th International Conference of the Society of Architectural Historians, Australia and New Zealand (SAHANZ), eds. David Beynon and Ursula de Jong (Geelong: SAHANZ, 2008), 1-32; Orr, "A Force for Federation," 100-110, $603-635$

20. Russell Ward, The Australian Legend (Melbourne: Oxford University Press, 1958), 11, 16-17, 309.

21. Helen Irving, To Constitute a Nation: A cultural history of Australia's Constitution (Cambridge: Cambridge University Press, 1999), 171-172; Deacon, "Political Arithmetic."

22. Irving, To Constitute a Nation, 172-174.

23. Orr, "A Force for Federation," 155.

24. The Industrial Progress of New South Wales: Being a Report of the Intercolonial Exhibition of 1870, at Sydney; together with a variety of papers illustrative of the industrial resources of the colony (Sydney: Thomas Richards, Government Printer, 1871).

25. Executive commissioner Patrick Alfred Jennings's closing speech reported in The Sydney Morning Herald, cited in Official Record of the Sydney International Exhibition, 1879 (Sydney: Thomas Richards Government Printer, 1881), ci.

26. J.J. Casey, "Final Report of the Proceedings of the Commissioner for the Melbourne International Exhibition, 1880, Together with a Statement of Accounts," Victoria Legislative Assembly Votes and Proceedings (1881), 5; Town and Country Journal (4 August 1888), 220

27. Orr, "A Force for Federation," 142-143.

28. Young gives a detailed account of the role of material goods in the genteel, middle class home, in Middle-Class Culture in the Nineteenth Century, 153-188.

29. Martha Sear, "'Common Neutral Ground:' Feminising the public sphere at tw o nineteenth-century Australian exhibitions of w omen's w ork," in Seize the Day, ed. Kate Darian-Smith et al. (Clayton: Monash University ePress, 2008), 14.4.

30. Ibid.

31. Patrick Alfred Jennings, "Report of the Executive Commissioner," in Official Record of the Sydney International Exhibition, 1879 (Sydney: Thomas Richards Government Printer, 1881), Ixxviii.

32. Paul Greenhalgh, Ephemeral Vistas: The Expositions Universelles, great exhibitions and world's fairs, 1851-1939 (New York: St Martin's Press, 1988), 198-207.

33. This average has been calculated by me and does not appear in Greenhalgh

34. This average has been calculated by me and does not appear in Greenhalgh.

35. Greenhalgh, Ephemeral Vistas, 191-192.

36. Ibid., 192.

37. Richard EN. Twopeny, Town Life in Australia, first published (London, 1883), republished (Sydney: Sydney University Press, 1973), 2.

38. David Blair, a distinguished former resident of Sydney returning from Melbourne after a thirty year absence, "Dottings from the Diary of a Travelling Technological Commissioner 1887," in Colonial Voices: Letters, diaries, journalism and other accounts of nineteenthcentury Australia, ed. Elizabeth Webby (St Lucia: University of Queensland Press, 1989), 188.

39. Patricia Grimshaw and Ann Standish, "Making Tasmania Home: Louisa Meredith's colonizing prose," Frontiers: A Journal of Women Studies 28:1-2 (2007): 1-17.

40. Catalogue of Exhibits in the New South Wales Court at the Melbourne International Exhibition, 1880: with preliminary remarks (Sydney: Thomas Richards Government Printer, 1880); Catalogue of Exhibits in the New South Wales Court, Centennial International Exhibition, Melbourne, 1888 (Sydney: C. Potter Government Printer, 1888).

41. Martha Sear, "Unw orded Proclamations: Exhibitions of w omen's w ork in Colonial Australia" (PhD diss., University of Sydney, 2000), 1. 42. Western Australia sent a very small exhibit. One of the 5 exhibitors w as female.

43. Greenhalgh observes that the ladies' courts generally "gave an overall impression that women had not entered into what w ere commonly considered the major disciplines;" Ephemeral Vistas, 185. There is little contemporary comment about the ladies' courts at the Australian international exhibitions. New spaper reports and official exhibition reports list the objects on display w ith little critical comment about the value or significance of the ladies' courts.

44. "The Ladies' Court," The Sydney Morning Herald (10 November 1879), 6.

45. "The Ladies' Court-V," The Sydney Morning Herald (24 March 1880), 7

46. Jeffrey Auerbach, The Great Exhibition of 1851: A nation on display (New Haven: Yale University Press, 1999), 66-67.

47. James D. McCabe, The Illustrated History of the Centennial Exhibition (Philadelphia: The National Publishing Company, 1876), 589595

48. The Ladies' Jury in 1879 comprised: Monsieur Léon Moonen (Chairman), Herr Moritz Bahse, Mr. G.C. Tuting, Miss Bourne, Mrs. EA Minchen, Miss Page and Mrs. J.C. Bannister-wife of the Secretary of the Victorian commissioners. Advice on the judging of fine arts exhibits was given by Monsieur Lucien Henry. See Official Record of the Sydney International Exhibition, 1879, 516-518.

49. I have not found a list of the women who organized the ladies' courts for either of the Melbourne international exhibitions, although the Ladies' Court in 1888 w as superintended by Mrs. Williams. Centennial International Exhibition Melbourne 1888-9 Official Record (Melbourne: Sands and McDougall Ltd, 1890), 243. The Ladies' Jury in 1880 comprised: Mrs. J.W. Stephen (President), Miss Florence E. Tripp, Mrs. E Prendergast, Mrs. E.M. Testar, Mrs. Murray, and Mrs. W.E King - wife of one of the Victorian commissioners. Official Record Melbourne International Exhibition 1880-81 (Melbourne: Mason, Firth and McCutcheon, 1882). I have found no mention of the Ladies' Jury for 1888 or of the aw ards made.

50. These statistics are derived from the same method of counting as used for the tables.

51. Kate Darian-Smith, "Images of Empire: Gender and nationhood in Australia at the time of Federation," in Britishness Abroad: Transnational movements and imperial cultures, ed. Kate Darian-Smith, Patricia Grimshaw and Stuart Macintyre (Carlton: Melbourne University Press, 2007), 162

52. Kerry Heckenberg, "Vulgar Art: Issues of genre and modernity in the reception of the flow er paintings of Elis Row an," in Impact of the Modern: Vernacular modernities in Australia 1870s-1960s, ed. Robert Dixon and Veronica Kelly (Sydney: Sydney University Press, 2008), 78.

53. Judith McKay, Ellis Rowan: A flower-hunter in Queensland (Brisbane: Queensland Museum, 1990), 1, 14-15

54. Official Record Melbourne International Exhibition 1880-81, ci.

55. Notes on the Sydney International Exhibition of 1879 (Sydney: Government Printing Office, 1880), 31.

56. Young, Middle-Class Culture in the Nineteenth Century.

57. Miss Waterhouse received an Honorable Mention in 1879 for her tabletop, which used the technique of "spattering" for the pattern of 

ferns.

58. Miss Hely and Miss Hooper exhibited in 1879 .

59. Grimshaw and Standish, "Making Tasmania Home," 7.

60. Roslyn Maguire, "Preserving the Memory of the Garden Palace in Print," in Colonial City Global City: Sydney's International Exhibition 1879, ed. Robert Freestone, Roslyn Maguire and Peter Proudfoot (Sydney: Crossing Press, 2000), 253. In 1880, the Central Board for the Protection of Aborigines in Victoria submitted examples of native weapons. See: Official Record Melbourne International Exhibition 1880-81, "Catalogue of General Exhibits-Victoria." In 1888, the Protector of Aborigines in Adelaide contributed waddies, shields, spearthrow ing sticks (w oomeras), boomerangs, clubs, spears, etc, Centennial International Exhibition Melbourne 1888-9 Official Record, "Catalogue of Exhibits-Class 38-Portable Weapons and Hunting and Shooting Equipment."

61. Official Record of the Sydney International Exhibition, 1879, 517-518.

62. John Morgan, The Life and Adventures of William Buckley: Thirty-two years a wanderer amongst the Aborigines of the then unexplored country round Port Phillip, now the Province of Victoria (Hobart: Archibald MacDougall, 1852).

63. Official Record of the Sydney International Exhibition, 1879, 517-518.

64. Official Record Melbourne International Exhibition 1880-81, "Catalogue of Fine Arts and General Exhibits;" Centennial International Exhibition Melbourne 1888-9 Official Record, "Catalogue of Exhibits".

65. Sharyn Pearce, Shameless Scribblers: Australian women's journalism 1880-1995 (Rockhampton: Central Queensland University Press, 1998), 1-11.

66. Serialized in The Age (Melbourne) new spaper in 1889, A Woman's Friendship w as republished in book form in 1988. Ada Cambridge A Woman's Friendship (Kensington: New South Wales University Press, 1988), 53.

67. Susan K. Martin, "'Surmounted by Stuffed Sheep': Exhibitions and empire in nineteenth-century Australia women's fiction," in Seize the Day, ed. Kate Darian-Smith et al. (Clayton: Monash University ePress, 2008), 13.1-13.10.

68. Young, Middle-Class Culture in the Nineteenth Century, 153-188

69. Mrs. EM. Perryman was a jew eler from Adelaide w ho exhibited in 1879 and 1880

70. Mrs. C.C. Armstrong from Victoria exhibited in 1888.

71. Misses Armfield from New South Wales exhibited in 1879

72. Mrs. Blayden Neill w as from Corow a, New South Wales. Official Record of the Sydney International Exhibition, 1879.

73. Centennial International Exhibition Melbourne 1888-9 Official Record, "Aw ards-Natural History."

74. Official Record Melbourne International Exhibition 1880-81, "Victoria-Class 64-Apparatus and Processes of Civil Engineering, Public Works and Architecture."

75. Wool classing examines the characteristics of fleece in its raw state. The characteristics of the fleeces identified in Mrs. Onslow's entry relate to the breed and sex of the sheep and are much more general than those of strength, colour, crimp, etc, in use today

76. Mrs. Elizabeth Coxen w on a First Degree of Merit in 1879 and Honorable Mention certificate in 1880 for her stuffed birds. McKay, Ellis Rowan, 14-15.

77. Official Record Melbourne International Exhibition 1880-81, ci.

78. Virginia Grant Darney, "Women and World's Fairs: American international expositions, 1876-1904" (PhD diss., Emory University, 1982) 201.

79. Maria Nugent, Women's Employment and Professionalism in Australia (Canberra: Australian Heritage Commission, 2002), 17-35.

80. Irving, To Constitute a Nation, 173.

81. Exhibit no. 1367 in Sydney International Exhibition 1879: Official Catalogue of Exhibits, New South Wales Court (Sydney: Thomas Richards Government Printer, 1879), 100; 'Manly Beach, Ocean Side' and 'Shell Bay, Manly' in Official Record Melbourne International Exhibition 1880-81, 523 .

82. Irving, To Constitute a Nation, 171-173.

83. Pearce, Shameless Scribblers, 38

84. Patricia Grimshaw, "Women's Suffrage in New Zealand Revisited: Writing from the margins," in Suffrage and Beyond: International feminist perspectives, ed. Caroline Daley and Melanie Nolan (New York: New York University Press, 1994), 26.

85. Ibid., 29

86. Kirsten Orr, "A Force for Urbanism and National Identity: Nineteenth century Australian exhibitions and their domestic exhibits," in ADDITIONS to Architectural History: XIXth Annual Conference of the Society of Architectural Historians, Australia and New Zealand (SAHANZ), ed. John MacArthur and Antony Moulis (Brisbane: SAHANZ, 2002), CD Rom.

87. Irving, To Constitute a Nation, 93.

Copyright ๑ 2011 Kirsten Orr and The Johns Hopkins University Press

\section{Welcome to Project MUSE}

Use the Search box at the top of the page to find book and journal content. Refine results with the filtering options on the left side of the results page. Use the Browse box to browse a selection of books and journals.

\section{Connect with Project MUSE}

Join our Facebook Page

Follow us on Twitter 